\title{
The other end of the couch
}

\author{
K. S. Jones
}

In 1979, I wrote a personal paper on psychiatry viewed from retirement (Jones, 1979). Six years later Wounded Healers included a chapter by me (Phoenix, 1985). In the first I was coy about the nature of my 'personal crisis'; in the second, I could pseudonymously be frank. Now, at 76, my further account appears above my own name.

It took endless years of cycles of hopeless incapacity and promising remission before the phoenix finally rose from the ashes. My affective and addictive problems presented my medical advisors with an ugly challenge to which they responded with varying adequacy; often they were friendly and sensible but sometimes I encountered unbelievable crassness, which it is tempting, but would be petty, to record here. Alcoholics Anonymous clearly helps some but did not help me, and I was mostly impressed by its disdain for other therapies and its general superficiality. A valuable outcome of orthodox treatment was abstinence, after 21 years dependence, from chlormethiazole, initially prescribed to relieve the anguish of an occasion of alcohol withdrawal. Otherwise little change occurred due in part to my intransigence and in part to therapists' limitations.

I ultimately regained health and comparative peace and resumed harmonious and productive involvement in family, domestic and social affairs. The factors involved in this miracle were my retreat from the approach of death; the steadfast support of my wife; the involvement of a gifted counsellor from the local community alcohol team; the adoption of an existential rather than a medical or a moralising - stance (Scammells, personal communication); and agerelated reduction in the ferocity of inner imperatives.

Psychotropic medication is now limited to an occasional $5 \mathrm{mg}$ tablet of diazepam. Total abstinence from alcohol has become an almost welcome habit and an anti-coagulant regime (undertaken because of embolic phenomena from hitherto unrecognised rheumatic heart disease) reinforces my resolution. My morale is vitally sustained by my knowledge that none of my former patients suffered because of my incapacity.

Has the practice of psychiatry improved or deteriorated since I entered it $\mathbf{4 8}$ years ago? Well, the Hogarthian scenes in the county asylum where I was appointed as a consultant would now be hard to find; indeed one of its three divisions has been replaced by a prison and another has been demolished to make room for a housing estate! Medical and surgical colleagues may now be better informed about psychiatry and its public image may also be more realistic. I hope too that funding has become more equitable, recalling as I do how the annual budget in the hospital referred to above was augmented by only tiny increments from its workhouse baseline of 1948 (it was as if all the therapeutic and humanitarian advances had never occurred, with a concomitant rise in cost!). On the other hand, what is happening to community care, that attractive alternative to the human warehouses' (Bavin, 1969) of the past? And are energetic and enthusiastic young doctors entering psychiatry in sufficient numbers? And why was the teaching hospital unit where I was an inpatient in the 1990s so very inferior to that in which I worked as a senior registrar in the 1950s?

Would I again choose psychiatry as my speciality? I think not. I would accept the misanthropic element in my personality rather than overcompensate for it by entering the most inter-personally demanding of occupations and opt instead for anatomy or pathology. Psychiatric practice reflects in miniature the universal deviations of mankind; to survive unscathed one must perhaps be very stupid or very callous - and I was neither. I was myself a general psychiatrist, a jack-of-all-trades, good in some areas, mediocre in others. But where are general psychiatrists now? (Steinberg, personal communication). Neuroses are treated by psychologists and counsellors, the elderly by psychogeriatricians, the criminal by forensic experts. Only the functional psychoses are left, and they are becoming the province of geneticists and neurochemists. And finally, in the field of dynamic psychotherapy, medical training is at best irrelevant, at worst, because of its emphasis on doing rather than being, inimical.

Readers may detect a note of petulance in some of my observations; they should not on that account complacently dismiss them. I have witnessed both sides of the consulting room 
and have encountered great variation in the quality of psychiatric practice. There is much to criticise but I salute those who strive to uphold the best traditions of psychological medicine.

\section{References}

Bavin. J. (1969) Plight of long-stay hospitals. British Medical Joumal, 3. 470.
JoNEs, K. S. (1979) Psychiatry observed-personal reflections in retirement. Bulletin of the Royal College of Psychiatrists, 3, 109-110.

PHoEnIX (1985) A kind of termination. In Wounded Healers (eds. V. Rippere \& R. Williams). pp. 133-143. Chichester: John Wiley.

K. S. Jones, Retired Consultant Psychiatrist, 13 The Mount, Dinas Powys, Vale of Glamorgan CF64 4DP

\begin{tabular}{|c|c|}
\hline \multicolumn{2}{|r|}{$\begin{array}{l}\text { Ethnicity: An Agenda for Mental Health } \\
\text { Edited by Dinesh Bhugra }\end{array}$} \\
\hline \multicolumn{2}{|c|}{$\begin{array}{l}\text { This book sets the scene for identifying and meeting the mental health needs of black and } \\
\text { minority ethnic groups. Clinicians, researchers, academics, hospital managers, commissioners } \\
\text { and voluntary organisation workers come together to discuss the problems in health care } \\
\text { delivery and the way of moving the agenda forward. In addition to multi-disciplinary working } \\
\text { the key emphasis here is in involving commissioners and voluntary organisations in deciding } \\
\text { how best to meet the needs of the communities. }\end{array}$} \\
\hline FEATURES: & $\begin{array}{l}\text { setting the agenda for meeting the needs of minority ethnic groups } \\
\text { multi-disciplinary input } \\
\text { multi-speciality within psychiatry }\end{array}$ \\
\hline READERSHIP: & $\begin{array}{l}\text { Mental health professionals, e.g. psychiatrists, trainees, nurses, } \\
\text { occupational therapists, psychologists and social workers, healthcare } \\
\text { managers }\end{array}$ \\
\hline \multicolumn{2}{|c|}{ August 1998, £25.00, 262pp approx, Paperback, ISBN 1901242153} \\
\hline $\sec _{4} \quad R$ & $\begin{array}{c}\text { LLEGE OF PSYCHIATRISTS, } 17 \text { BELGRAVE SQUARE, LONDON SW1X 8PG } \\
:+44 \text { (0) } 1712352351, \text { EXT } 146 \text { FAX: }+44(0) 1712451231 \\
\text { http://www.rcpsych.ac.uk }\end{array}$ \\
\hline
\end{tabular}

